\title{
Implikasies vir die leksikografie van die klassifikasie van plante en diere in die volkstaksonomie
}

\author{
J.C.M.D. du Plessis, Buro van die Woordeboek van die Afrikaanse Taal
}

\begin{abstract}
Implications for Lexicography of the Classification of Plants and Animals in Folk Taxonomy. In this essay the scientific taxonomic system is contrasted with the folk taxonomic system through the use of relational semantic models: the basis for the former is chiefly meronymy, while that for the latter is mainly modification. Corresponding to these systems two kinds of dictionaries can be distinguished: the encyclopedic dictionary and the standard dictionary which are based on extensional and stereotypical concepts respectively. In a scientifically based culture the scientific taxonomical concepts influence the folk taxonomical concepts of plants and animals. This fact should be taken into account in definitions in a comprehensive explanatory dictionary which is based on prototypical concepts and takes a position between the encyclopedic dictionary and the standard dictionary.
\end{abstract}

Keywords: LEXICOGRAPHY, SCIENTIFIC TAXONOMY, FOLK TAXONOMY, SEMANTIC RELATIONS, MERONYMY, MODIFICATION, COMPREHENSIVE EXPLANATORY DICTIONARY, ENCYCLOPEDIC DICTIONARY, STANDARD DICTIONARY

Opsomming: In hierdie opstel word die wetenskaplike taksonomiese stelsel met die volkstaksonomiese stelsel gekontrasteer deur die gebruik van relasionele semantiese modelle: die basis vir eersgenoemde is hoofsaaklik meronimie, terwyl dié vir lasgenoemde veral modifikasie is. Oreenstemmend met hierdie stelsels kan twee soorte woordeboeke onderskei word: die ensiklopediese woordeboek en die standaardwoordeboek wat gebaseer is op ekstensionele en stereotipiese konsepte onderskeidelik. In 'n wetenskaplik gebaseerde kultuur beïnvloed die wetenskaplike taksonomiese konsepte die volkswetenskaplike konsepte van plante en diere. Hierdie feit behoort in aanmerking geneem te word by definisies in ' $n$ omvattende verklarende woordeboek wat op prototipiese konsepte gebaseer is en 'n plek tussen die ensiklopediese woordeboek en die standaardwoordeboek inneem.

Sleutelwoorde: LEKSIKOGRAFIE, WETENSKAPLIKE TAKSONOMIE, VOLKSTAKSONOMIE, SEMANTIESE RELASIES, MERONIMIE, MODIFIKASIE, OMVATTENDE VERKLARENDE WOORDEBOEK, ENSIKLOPEDIESE WOORDEBOEK, STANDAARDWOORDEBOEK 


\section{Inleiding}

In 'n bespreking oor die opname van vakterme in die Woordeboek van die Afri. kaanse Taal meld Swanepoel (1989) dat resensente telkens twee algemene beginsels stel, nl. dat vakterme slegs opgeneem moet word op grond van hul gebruik in die omgangstaal en hul definieerbaarheid in leketaal. Aangesien hy ook meermale in sy behandeling van dié twee aspekte na uitsprake van Hauptfleisch (1982) verwys, wil ek Swanepoel se studie as uitgangspunt neem vir hierdie artikel wat ek graag aan mnr. D.C. Hauptfleisch opdra met wie ek die afgelope 28 jaar in verskillende hoedanighede by die Buro van die Woordeboek van die Afrikaanse Taal saamgewerk het.

Omdat die verskillende afdelings van die vakterminologie verskillende vereistes ten opsigte van opname in eentalig verklarende woordeboeke stel, beperk ek my tot ' $n$ behandeling van plant- en diemame in die volkstaksonomie. In my bespreking sal ek hulle telkens met benamings in die wetenskaplike taksonomie vergelyk. Dit geskied onder die volgende twee hoofde: eerstens, die wetenskaplike en die volkstaalstelsels en, tweedens, die wetenskaplike en die volkstaksonomiese stelsels.

\section{Die wetenskaplike en die volkstaalstelsels}

\subsection{Probleemstelling ten opsigte van die wetenskaplike en die volkstaal- stelsels}

By die benaming van plante en diere kan twee stelsels onderskei word: 'n wetenskaplike en 'n volkstaksonomiese stelsel. In die wetenskaplike taksonomie word alle bekende plante en diere benoem, in die volkstaksonomie verkry slegs die bekendste plante en diere name. Vir sommige plante en diere is daar dus geen volksname nie, vir ander word dikwels in verskillende dele van die land of by bepaalde groepe mense dieselfde volksnaam of verskeie volksname gebruik: dieselfde volksnaam word aangetref vir verskeie soorte wat meermale nie eers verwant is nie, terwyl verskillende volksname wat dikwels ook ander soorte benoem, vir 'n enkele soort voorkom. By wetenskaplikes lei dit om verskillende praktiese redes, veral om verwarring by identifikasie te voorkom en verbetering van kommunikasie te bewerkstellig, tot die skepping en standaardisering van name. Hulle skep gewone name vir dié plante en diere wat geen name het nie, bv. deur. die toevoeging van beskrywende komponente by volksname of die vertaling van Latynse of anderstalige benamings, of hulle standaardiseer volksname waarvan daar meer as een bestaan of wat verskillende soorte benoem, bv. deur die wyds verspreide en algemeens gebruikte of mees beskrywende of gepaste naam vir een soort te kies. 


\subsubsection{Wetenskaplikes se benadering van die twee taksonomiese stelsels}

Om die skrywers van meer of minder wetenskaplike werke se verskillende opvaltings en metodes rakende die skepping en standaardisering van plant- en diername te illustreer, kan die volgende Suid-Afrikaanse publikasies oor inheemse visse, voëls en bome as voorbeelde gebruik word.

As eerste voorbeeld dien werke oor inheemse visse.

Barnard stel sy benadering ten opsigte van die volksname van visse soos volg in die inleiding tot sy boek (1947: x): "It would be impossible here to quote all the various names given to our common fishes; only the best-known name is given, or, if the fish is well-known but differently named in the Cape and Natal, the respective local names. Several names specially invented for the purpose of this booklet will, it is hoped, eventually find general favour. That some of the rarer and deep-water fishes are left without names is of little consequence."

Hierteenoor staan die siening van J.L.B. Smith (1949: 22) wat hom teen doelbewuste standaardisering en kunsmatige naamgewing uitspreek: "Synonymy is not undesirable as long as it is correlated ... As long as they (anglers) can refer to a work which correlates the names, preferably with good pictures of the species, there is no reason why all the names should not continue to be used ... A feature of this work is the list of such names with localities given with the species. The system here adopted together with full indexing should enable anglers everywhere to smooth out their difficulties in the matter of common names. The passing of many of these names would be a pity as they are of local and historic interest."

Volgens Margaret M. Smith (1975: 2) kan hierdie opvatting nie meer gehuldig word nie: "Today the necessity to standardise the common names of our fishes is recognised by all sections of the community including the angling fraternity. ... Commerce, law and sport need trade names, names for aquarium fishes, for legal terminology and for general use. Substitutes for scientific names are needed for the increasing number of inland aquaria, for popular and scientific writing in encyclopaedias, dictionaries, popular and scientific magazines, newspaper reports and record lists." Met dié doel voor oë het sy dus volgens bepaalde beginsels en aanbevelings (1975: 3-5) 'n lys met gewone name opgestel: waar goed gevestigde name nie bestaan het nie, is name veral wedersyds uit Engels of Afrikaans vertaal. In hul hersiene uitgawe van J.L.B. Smith se werk gebruik Smith en Heemstra (1988) dan ook die name uit hierdie lys.

As tweede voorbeeld behandel ek publikasies oor inheemse voëls.

Reeds vanaf die eerste uitgawe van sy boek oor voëls meld Gill (1936: 15-16): "So far only the best-known birds have Afrikaans names that are really distinctive and usable." Hy vervolg: "If usable Afrikaans names for all the birds are wanted, nine-tenths of them will have to be deliberately invented, and will only gradually work their way into general usage." Dit gaan dus ook vir hom om twee werksaamhede: naas die versameling en sistematisering van 
reeds gangbare name, ook die skepping van nuwe name. In die derde uitgawe van sy boek (1945: 16) voeg hy ' $n$ nota by dat die Afrikaanse name wat in Roberts se boek vir al die voëlsoorte aangegee word, hopelik in dié vermelde tekorte sal voorsien.

Oor die aangee van volksname by voëlsoorte skryf Roberts in die inleiding tot die eerste uitgawe van sy boek (1940: xviii): "In South Africa the choice of single names for certain species remains to be made in the case of many, and I have had to search for appropriate ones amongst those in use with an eye to causing as little disturbance of current usage as possible." Hierdie opmerking het ook in die hersiene uitgawes (1957: xxiii en 1970: xviii) behoue gebly. In die voorwoord tot die sewende uitgawe van Gill se boek (1964: 15) word gesê dat die Afrikaanse name wat gebruik word, meestal dié van Roberts is, maar dat dit moontlik is dat sommige van hulle vervang sal word "either by colloquial names already in use in some part of the country or other or by simple names deliberately invented by Afrikaans-speaking ornithologists".

Prozesky (1974: iv) sê in sy inleiding: " $n$ Poging word aangewend om die gebruiklikste en gewildste Afrikaanse name vir ons voëls te vind. Die hoop word uitgespreek dat die name wat in hierdie gids gebruik word, vir almal aanneemlik sal wees." Hy wil die misverstand wat die Afrikaanse name wat in Roberts gegee word, in sommige gevalle veroorsaak het, uit die weg ruim: "Daar is gepoog om die Afrikaanse voëlname op ' $n$ meer logiese grondslag te plaas." In die inleiding tot die sewende uitgawe van Roberts (1984: xxix) word oor die Afrikaane volksname gesê: "Once again, the idea has been to produce a list of names acceptable to the greatest majority of Afrikaans-speaking people. Most of the names are well established in South African usage anyway. Some of the innovations will stay, others will change."

As derde voorbeeld gebruik ek werke oor inheemse bome.

Uitgaande van die doelstelling "to present the trees of our country (and ... those of adjoining territories as well) to a lay public in a simple form", sluit Palmer en Pitman (1972: ix- $x$ ) hulle aan by die groep wat meen "that common names should be presented as they are and that ... common names in all their weal th reflect the place of a tree in the life and history of a community". Om egter ook die groep tegemoet te kom wat meen gewone name "should be restricted in the cause of easy identification and 'communication', a common name being used for one species only and not for two or more - and ... the most widely used common name, or the most appropriate, should be universally adopted and all others excluded", gee hulle ' $n$ lys van die algemeenste en soms die mees gepaste wat moontlik as standaardvorm bestempel sou kan word, eerste. Soms, wanneer geen gewone naam in Engels of Afrikaans beskikbaar is nie, is ' $n$ inheemse naam of ' $n$ vertaling daarvan gebruik.

Alhoewel hulle die klem sterker op standaardisering plaas, is laasgenoemde ook die metode wat deur De Winter e.a. (1966: 9) en later deur Van Wyk (1973) gevolg word: "Volksname is voorasnog onbetroubaar, maar in populêre werke sal daar altyd 'n behoefte aan die volksname by die publiek 
gevoel word. Met die oog daarop het die skrywers die Afrikaanse en Engelse name gekies wat na hul mening die meeste gebesig word ... Hopelik sal hulle mettertyd 'gestandaardiseer' en algemeen aanvaar word. Waar een volksnaam in albei landstale ingeburger is, word net daardie naam gegee. Ander volksname verskyn onder 'n aparte hofie en sluit inboorlingbenaminge in." Die publikasie van De Winter e.a. bevat ook as byvoegsel die Nasionale Boomlys van Suid-Afrika, waarvan die eerste aparte uitgawe deur De Winter en Vahrmeijer (1972) voorberei is. Inligting oor die verspreiding en frekwensie van gebruik van die gewone name word gevra met die oog op die kies van standaardname vir die verskillende soorte.

Uit die voorafgaande ondersoek van die benaderingswyses van verskillende wetenskaplikes blyk die volgende ten opsigte van plant- en diername: Waar dit gaan om minder bekende plant- en diersoorte wat nie gewone name besit nie, is ' $n$ lys gemaakte gewone name nuttig vir kommunikasie. Waar dit gaan om bekende plant- en diersoorte wat reeds volksname het, is enersyds 'n volledige lys volksname vir identifikasie en andersyds 'n gestandaardiseerde lys volksname vir kommunikasie nodig. Dit is veral essensieel by werke wat saamgestel is om ' $n$ bepaalde funksie te vervul, soos die uitkenning van geskikte grassoorte vir dierevoeding, bv. Chippindall (1946), die beskrywing van geneeskundige en giftige plantsoorte, bv. Watt en Breyer-Brandwijk (1962) of die bepaling van onkruidagtige indringerplante, bv. Wells e.a. (1986).

\subsubsection{Vergelyking van die twee taksonomië̈}

Dit is nou nodig om die wetenskaplike en die volkstaksonomiese stelsels duideliker te omskryf. Daar bestaan twee wetenskaplike benamingstelsels, een met Latynse benaminge en een met gewone benaminge. Soos ek in par. 3.1.2 hieronder uiteensit, steun die Latynse benamingstelsel op streng voorskrifte: elke verskillend geïdentifiseerde plant- en diersoort word benoem met 'n enkele naam binne ' $n$ bepaalde klassifikasiemetode. Soms word volksname in hierdie stelsel geïnkorporeer (vgl. Smith 1956: 29-30). Die gewone benamingstelsel wat op hierdie Latynse benamingstelsel gegrond is, gebruik of gestandaardiseerde volksname óf geskepte gewone name wat naas die Latynse name aan plant- en diersoorte gegee word: hier ook 'n enkele naam vir elke aparte soort wat deur die wetenskaplike klassifikasiemetode onderskei is. Die gestandaardiseerde volksname wat in die wetenskaplike benamingstelsel opgeneem word, word op hierdie manier nuut gekonseptualiseer.

Soos ek in par. 3.2.1 hieronder aantoon, berus die volkstaksonomiese stelsel op 'n heeltemal ander basis: omdat daar nie 'n streng wetenskaplike klassifikasiestelsel onderliggend is aan die volksbenamingstelsel nie, word een volksnaam vir verskeie soorte gebruik en ontstaan verskillende volksname vir 'n enkele soort. (Oor die herkoms van Afrikaanse name vir plante sien Scholtz 1975 en Smith 1956: 12-50, en vir diere sien Scholtz 1975.).Van die geskepte gewone name dring dikwels tot die algemene taal deur sodat hulle in die volks- 
taksonomiese stelsel geïnkorporeer word. Dit gebeur minder dikwels met die Latynse benaminge. Generiese name word soms as verafrikaanste of onveranderde leenwoorde vir ' $n$ individu, maar nie vir 'n geslag nie gebruik. Name van groepe bokant generiese vlak word partykeer in Afrikaans vertaal, maar bly deel van die wetenskaplike taksonomie.

Omdat dieselfde Afrikaanse naam gevolglik in twee verskillende benamingstelsels kan voorkom, neem dit ook ' $n$ ander plek in elkeen van die klassifikasiestelsels onderliggend aan hierdie benamingstelsels in. Dit het, soos ek in par. 3.2.3 hieronder verduidelik, belangrike implikasies vir die aard van die definisies van volksname.

2.2 Plasing van die twee taksonomieë binne die wetenskaplike en die volkstaalstelsels

\subsubsection{Kontrastering van die twee stelsels}

Op grond van die onderskeid tussen die twee taksonomiese stelsels is dit moontlik om die verskil tussen wetenskaplike en volksbenamingstelsels te formuleer. (Ek maak hier gebruik van enkele insigte oor wetenskaplike en tegniese woorde van Béjoint 1988: 354-368 en veral oor benaminge uit die biologie van Callebaut 1983: 33-52 en Piotrowski 1986.)

Wetenskaplikes en gewone mense sien en interpreteer die werklikheid verskillend omdat hulle verskillende gesigs- en uitgangspunte het. Die konseptuele struktuur van die biologiese wetenskappe sentreer om gespesialiseerde kennis, dié van die volksbiologie om volkswetenskaplike kennis. Dit kom in die taal tot uitdrukking in die vorm van verskillende terme. Hierdie verskille in terminologie is funksioneel omdat dit verwys na verskillende aspekte van dieselfde verskynsel. Wetenskaplike taal is nie gebaseer op die kultuur van die gewone taal nie, maar op ' $n$ wetenskaplike kultuur wat gedeeltelik met die gewone kultuur oorvleuel.

Wetenskaplike name is wetenskapgesentreerd, volksname mensgesentreerd. Die graad van tegnisiteit van die twee benamingstelsels verskil. Die konsepte wat deur wetenskaplike woorde aangedui word, kan gewoonlik net deur wetenskaplikes gekonseptualiseer en deur gespesialiseerde wetenskaplike woorde gedefinieer word. Selfs waar die gewone benaminge van die wetenskaplike stelsel en die volksbenaminge van die volkswetenskaplike stelsel ooreenstem, sal hulle verskillend deur wetenskaplikes en gewone mense gekonseptualiseer word.

Wetenskaplike terme word in gespesialiseerde kontekste gebruik waarin hulle ' $n$ belangrike plek inneem, terwyl volkswetenskaplike woorde in algemene kontekste voorkom waarin hulle ' $n$ minder belangrike rol vervul. Wetenskaplike terme is beperk tot aanwending in noukeurig bepaalde omstandighede, volkswetenskaplike woorde vind vrylik toepassing in 'n verskeidenheid situasies. Waar die betekenis van wetenskaplike name hoofsaaklik onafhanklik 
is van die kontekste waarin hulle voorkom, is die betekenis van volksname grotendeels afhanklik van die kontekste waarin hulle gebruik word.

in Kenmerk van wetenskaplike taal is die toekenning van eenduidige en ondubbelsinnige terme aan duidelik omskrewe konsepte, terwyl 'n eienskap van volkswetenskaplike taal die voorkoms van meerduidige en dubbelsinnige woorde is waarmee betreklik onduidelike konsepte uitgedruk word. Daar word in wetenskaplike taal geprobeer om die betekenis van 'n term objektief vas te stel sodat daar geen verskille in interpretasie kan ontstaan nie. Die betekenis van volkswoorde verander deur gebruik. Aan hulle word talle subjektiewe konnotasies geheg volgens die situasie waarbinne hulle aangewend word en die persoon teenoor wie hulle gebesig word. Volkswoorde word gekenmerk deur ' $n$ hoë mate van polisemie, metaforiese uitbreidings en toepassings.

In wetenskaplike taal word een konsep verkieslik met een term uitgedruk, in die volkstaal bestaan daar dikwels verskeie sinonieme vir ' $n$ enkele konsep. Nuwe wetenskaplike benamings word maklik gemaak volgens bepaalde voorskrifte, terwyl volkswetenskaplike benamings wat meestal spontaan ontstaan, deur gebruik gestereotipeer word. Wetenskaplike terme kan dus na willekeur verander word sodat hulle gou kan verouder. Indien volkswetenskaplike terme verouder, vind dit baie stadiger plaas. Wetenskaplike benamings is grotendeels universeel en interlinguaal, terwyl volksbenamings gewoonlik nasionaal en intralinguaal is. Gevolglik kry 'n mens 'n groot sosiolinguistiese en taalgeografiese verskeidenheid by volksname.

\subsubsection{Teoretiese fundering van die twee stelsels}

Om die samehang en verskil tussen die wetenskaplike stelsel en die volkstaalstelsel aan te toon, kan Baldinger (1980: 136) se begrippe van onomasiologie en semasiologie gebruik word: "Designation" enersyds "proceeds from the concept towards the acoustic image (signifiant)"; "signification" andersyds "proceeds from the acoustic image (signifiant) towards the concept". Akoestiese beeld en konsep, signifikasie en designasie word in vier verskillende strukture aangetref. Mikrostrukture is gebonde aan een konsep of aan een akoestiese beeld: designasies en signifikasies wat aan 'n enkele konsep en 'n enkele akoestiese beeld gebind is, vorm onderskeidelik ' $n$ veld van designasies (onomasiologiese veld) en 'n veld van signifikasies (semasiologiese veld). 'n Veld van designasies, sinonimie, word moontlik gemaak deur die feit dat 'n enkele konsep deur verskillende akoestiese beelde uitgedruk kan word, terwyl 'n veld van signifikasies, polisemie, moontlik gemaak word deur die feit dat daar geen direkte verband tussen die akoestiese beeld en die ekstralinguistiese werklikheid bestaan nie. Makrostrukture word op formele en op konseptuele vlak onderskeidelik deur die akoestiese beelde en die begripsobjekte onderling gevorm. Die onomasiologiese gesigspunt is dié van die spreker wat die signifieerder moet kies uit al die uitdrukkingsmoontlikhede; die semasiologiese gesigspunt 
is dié van die hoorder wat die gesignifieerde moet vasstel uit al die moontlike betekenisse.

By die gebruik van woorde vind daar 'n gedurige wisselwerking tussen spreker en hoorder plaas. Dit bring sosiolinguistiese, chronologiese en taalgeografiese stylaspekte die taal binne. Baldinger verduidelik dit aan die hand van Bühler (1934: 28) se model van die linguistiese teken: Dit is 'n voorstelling (Darstellung) op grond van sy gebondenheid aan voorwerpe en verbande; in uitdrukking (Ausdruck) op grond van sy afhanklikheid van die spreker wie se wese dit openbaar; en ' $n$ beroep (Appell) op grond van sy gerigtheid op ' $n$ hoorder wie se eksterne en interne gedrag dit beinvloed. Woordgebruik is dus terselfdertyd ' $n$ voorstelling, ' $n$ uitdrukking deur die spreker en ' $n$ beroep op die hoorder. Hierdeur word die verskil duidelik tussen wetenskaplike taal en volkstaal. By eersgenoemde word hoofsaaklik die representatiewe aspek na vore gebring, by laasgenoemde ook die ekspressiewe en appellatiewe aspekte. Daarom is wetenskaplike taalgebruik grotendeels konteksonafhanklik, terwyl volkstaalgebruik meestal konteksafhanklik is.

Absolute sinonimie en monosemie het slegs betrekking op die representatiewe funksie van die linguistiese teken. Die onderskeiding tussen sinonieme en die ontwikkeling van polisemie ontstaan deur die benutting van die ekspressiewe en appellatiewe funksies tussen die spreker en die hoorder. Tot die sinonimie en monosemie wat berus op die representatiewe waarde, word onderskeidende en bykomstige elemente toegevoeg deur die wisselwerking tussen spreker en hoorder wat binne 'n bepaalde sosiolinguistiese, temporele en taalgeografiese milieu optree. Vanweë hul gebondenheid aan 'n bepaalde milieu moet dié sinonieme en poliseme gevolglik dikwels in die leksikografie geëtiketteer word (vgl. Du Toit 1989).

\subsubsection{Die twee stelsels en twee verbandhoudende woordeboeksoorte}

Die twee stelsels van die wetenskaplike taal en die volkstaal waar die verhouding tussen die skrywer en die hoorder onderskeidelik meer en minder neutraal is, sluit ongeveer aan by en stem naastenby ooreen met die twee kontrasterende woordeboeksoorte, die ensiklopediese en die standaardwoordeboek, wat Geeraerts (1984 en 1985) onderskei deur gebruikmaking van die konsepte, prototipe, ekstensie en stereotipe. Hy ontleen sy klassifikasie aan twee semantiese teorieë, Rosch se psigologiese en Putnam se filosofiese benadering (vir 'n uiteensetting hiervan sien Rosch 1975, Mervis en Rosch 1981 en Putnam 1975). By Rosch kry hy die opvatting van die prototipiese konsep, terwyl hy aan Putnam die idee van die ekstensionele en stereotipiese konsepte ontleen.

Prototipes word deur Geeraerts (1984: 4) beskou as metodologiese eerder as streng psigologiese konsepte: "They constitute the full set of prototypically clustered senses that a lexical item receives within a language, dependent on stylistic, psychological, sociolinguistic, chronological, referential, or other factors." Die struktuur van semantiese variasie wat deur die leksikografie bloot- 
gelê word, is dieselfde as die struktuur wat deur die prototipiese teorie aan lekekstensionele en stereotipiese konsepte besondere verteenwoordigers van die volle prototipiese groep van toepassings van 'n item: "Technically speaking, one might say that extensional concepts within the cluster are singled out in scientific or technically expert contexts, whereas stereotypical concepts are set off in normative or pedagogical contexts. In this sense, they are comparable to the other contextual variants within the cluster, such as the sociolinguistically or geographically restricted senses of an item" (Geeraerts 1984: 5).

Deur middel van hierdie uitgangspunt onderskei Geeraerts (1984: 3) dan 'n drietal woordeboeke. Die omvattende algemene woordeboeke wat inligting oor die nie-konvensionele taalgebruik verskaf en 'n beskrywing van linguistiese variasie gee, gaan uit van die prototipiese konsep, die maksimale kompleks van semantiese variante. Die ensiklopediese woordeboeke enersyds en die standaardwoordeboeke andersyds wat gesaghebbende vakkundige kennis en konvensionele linguistiese inligting aanbied, beklemtoon die wetenskaplike en tegniese en die sentrale en normatiewe nuanses en betekenisse van die prototipiese kompleks. In die leksikografie gebeur dit gewoonlik dat daar by die omskrywing van plant- en diername, vanweë praktiese oorwegings, uitgegaan word van die wetenskaplike definisie waarby dan aspekte van die volksdefinisie gevoeg word (vgl. Wierzbicka 1985: 195-196, asook Callebaut 1983: 48 wat die definisies van voëlname in Franse woordeboeke ondersoek het).

In die volgende bespreking wil ek insigte van die relasionele semantiek gebruik om die twee taksonomiese stelsels, die wetenskaplike en die volkse, verder te karakteriseer. Dit sal ook lig werp op die wetenskaplike en volkse definiëring van plant- en dierbenamings.

\section{Die wetenskaplike en die volkstaksonomiese stelsels}

\subsection{Ontleding van wetenskaplike en volkswetenskaplike taàl met behulp van relasionele modelle}

Reeds in 'n vroeë opstel merk Frawley (1980-1981) op dat "the technical vocabulary of science is constitutive of science". Hy beweer dat die suksesvolle gebruik van leksikografiese tegnieke in die wetenskapsfilosofie bewys, eerstens, dat op 'n sekere vlak gewone kennis en wetenskaplike kennis dieselfde struktuur het en, tweedens, dat wetenskap 'n simboolsisteem is waartoe ' $n$ mens toegang kan verkry deur 'n geldige metataal. Hierdie gevolgtrekkings volg hy op in 'n latere studie (1988) waarin hy, soos reeds in sy vroeëre opstel, relasionele modelle wat vir die leksikografie ontwerp is, gebruik vir 'n verstaan van die semantiese struktuur van wetenskaplike taal en 'n studie van die maniere waarop hierdie strukture verander. Elke vertakking van die wetenskap het sy eie wetenskaplike subtaal en veranderinge in daardie subtaal toon die veranderinge in die fokus van die wetenskap self. Hierdie insigte van Frawley is nie 
net nuttig vir die ontleding van suiwer wetenskaplike taal nie, maar ook vir die volkswetenskaplike taal.

Die probleem met relasionale modelle is enersyds dat die struktuur van verbande tussen voorwerpe uit die eksterne werklikheid eerder as tussen woorde beskryf word en andersyds dat die konkrete leksikon uit die oog verloor word deur die abstrakte beskrywing van die semantiese verwantskappe tussen konsepte. 'n Mens moet dus uitgaan van 'n leksikale basis by die beskrywing van stelsels nie net in die suiwer wetenskappe nie, maar ook in die volkswetenskappe. Daar is twee redes hiervoor: 'n leksikale model van wetenskaplike subtaal fokusseer eerstens op inhoud en tweedens op oppervlakkollokasie. Dit is belangrike aspekte vir Frawley wie se doelstelling dit is om die wetenskaplike subtaal van die gewone subtaal af te grens. Hy gebruik dan ook die relasies wat Mel'chuk en Zholkovsky vir hul verklarende kombinatoriese woordeboek onderskei het (vir 'n samevatting hiervan sien Mel'chuk en Zholkovsky 1988).

\subsubsection{Kontrastering van die twee taksonomie $\ddot{e}$}

Die wetenskaplike stelsel word dikwels gesuperponeer op die informele stelsel van die volkstaal. Maar alhoewel daar, soos reeds aangetoon, taksonomieë in die biologiese wetenskap en in die volkswetenskap bestaan, verskil hulle opvallend van mekaar. Die rede wat ek hiervoor wil aanvoer, is dat hierdie twee taksonomiese relasies op veral twee ander relasionele modelle berus. Die wetenskaplike taksonomie staan primêr in noue verband met meronimie, veral die onderafdeling daarvan wat as deel-geheel bekend is, en slegs sekondèr met modifikasie. Die volkstaksonomie hou basies verband met modifikasie, en wanneer deel-geheel wel voorkom, is dit in 'n aspek wat eerder te doen het met modifikasie as met meronimie. Meronimie word wel by die volkstaksonomie aangetref in sy onderafdeling versameling-lid.

Hierdie verhoudings kan kortliks soos volg omskryf word (vgl. Evens e.a. 1980 en meer bepaald Markowitz 1988, Chaffin en Herrmann 1988 en Iris e.a. 1988). Taksonomie is ' $n$ verwantskap wat die lidmaatskap van ' $n$ individu van 'n groep individue in 'n groter groep toon. In Afrikaans word dit dikwels uitgedruk deur die werkwoord "is" of "is 'n soort". Meronimie is die verwantskap wat iets identifiseer as 'n deel of gedeelte van iets anders. In Afrikaans word dit gewoonlik weergegee deur die werkwoord "het", "is deel of 'n gedeelte van" of die besitlike vorm. Dit het verskillende onderafdelings (sien veral Iris e.a. 1988). Die twee wat hier van belang is, is deel-geheel en versameling-lid. Modifikasie is ' $n$ verhouding wat onderskeidende en kenmerkende attribute benoem wat betref kleur, grootte, vorm, habitat, gedrag of handeling, of evaluerende menings oor hulle uitspreek. 


\subsubsection{Karakterisering van die twee taksonomie $\ddot{e}$}

Klassifikasie van plante en diere in die biologiese wetenskappe word gebaseer op die anatomie, maar ook op meer geredelik waameembare uiterlike eienskappe waardeur die verwantskappe van spesies getoon kan word. Die spesies word dan volgens die graad van verwantskap gerangskik in geslagte, families, ordes, klasse en afdelings. In hierdie groepe kan ook tussenverdelings gemaak word wat aangedui word met die voorvoegsels sub- en super-. Die toekenning van name aan taksonomiese groepe word bepaal deur nomenklatoriese tipes. 'n Nomenklatoriese tipe is daardie konstituerende element van 'n groep waaraan die groep se naam permanent gekoppel is.

Die benaming en beskrywing geskied volgens die reëls en voorskrifte in die verskillende internasionale nomenklatoriese kodes (sien Savory 1962: 41-78 en Jeffrey 1973: 5-6). Daarvolgens is dit verpligtend om plante en diere deur gebruikmaking van taxa op 'n bepaalde manier in Latyn te benoem en te beskryf (vgl. Savory 1962: 93-106 en Jeffrey 1973: 7-11, asook, wat plante betref, Stearn 1966). Vir elke spesie is daar slegs een geldige naam, 'n binomiale naam waarvan die eerste gedeelte die genus en die tweede gedeelte die spesifieke spesie benoem. ' $n$ Trinomiale naam word soms gegee aan geografiese variëteite, nou bekend as "subspesies". Hierdie wetenskaplike stelsel van benaming word meestal gevolg wanneer die Latynse naamstelsel met 'n gewone naamstelsel vervang word. Die begrensing van die taxa is onderhewig aan verandering in die lig van die ontdekking van nuwe spesies, die herinterpretasie van feite of die regstelling van foute betreffende die verwantskappe van die verskillende soorte. Wanneer sommige spesies op grond hiervan twee of meer verskillende name gekry het, word die oudste naam gewoonlik as die geldige naam en die latere naam of name as junior sinonieme beskou. Indien 'n spesie by 'n ander geslag ingedeel word, word die vroegste spesifieke lid van die spesienaam behou. Die beskrywing van die plant of dier gee onderskeidende en wesenlike kenmerke in ' $n$ vaste volgorde sodat beskrywings maklik met mekaar vergelyk kan word.

'n Wetenskaplike taksonomie bestaan dus uit gekonseptualiseerde prototipes wat berus op ekstensie (vgl. par. 2.2.3 hierbo). Alhoewel dit op die konkrete werklikheid gebaseer is, bestaan dit uit abstrakte vlakke. Cruse (1986: 179) sê: "Any taxonomy can be thought of in part-whole terms (although the converse is not true): a class can be looked on as a whole whose parts are its subclasses. Corresponding to each of the common nouns constituting a typical taxonomy, there exists a proper noun labelling the class as an individual." 'n Taksonomie kan dus op hierdie manier in 'n meronomie verander word (vgl. ook Cruse 1986: 185) wat aantoon dat dit nouer bande met die konkrete werklikheid het as 'n taksonomie. Dit geld net vir 'n wetenskaplike taksonomie. 'n Volkstaksonomie het juis 'n noue band met die konkrete werklikheid deurdat dit berus op verwantskappe wat tussen soortname bewerkstellig word. 'n Volkstaksonomie bestaan dus uit gekonseptualiseerde prototipes wat steun op 
stereotipie (vgl. par. 2.2.3 hierbo). Maar wat die inhoud en samehang van hierdie prototipes is, is nie so maklik aanwysbaar soos by wetenskaplike taksonomieë nie. Waar daar by die wetenskaplike taksonomie duidelike kategorievlakke is, is die kategorievlakke by die volkstaksonomie minder duidelik.

Berlin e.a. (1973: 214-215) formuleer die volgende beginsels betreffende volksgroeperings:

"(1) In all languages it is possible to isolate linguistically recognized groupings of organisms of varying degrees of inclusiveness. These classes are referred to here as taxa and can be illustrated by the groupings of organisms indicated by the names oak, vine, plant, redheaded woodpecker, etc., in English.

(2) Taxa are further grouped into a small number of classes known as taxonomic ethnobiological categories. These ethnobiological categories, definable in terms of linguistic and taxonomic criteria, probably number no more than five. They may be named as follows: unique beginner, life form, generic, specific, and varietal ...

(3) The five universal ethnobiological categories are arranged hierarchically and taxa assigned to each rank are mutually exclusive, except for the unique beginner, of which there is only one member."

Wat die relatiewe belang van hierdie vyf groeperings betref, maak Berlin e.a. (1973: 216) die volgende opmerkings ten opsigte van generiese taxa:

"Generic taxa are the basic building blocks of all folk taxonomies. They represent the most commonly referred to groupings of organisms in the natural environment, are the most salient psychologically and are likely to be among the first taxa learned by the child."

Tereg kritiseer Wierzbicka (1975: 150) die kriteria wat deur Berlin e.a. voorgestel is omdat dit nie altyd voldoende is om biologiese konsepte aan die verskillende vlakke toe te ken nie.

Om dit te illustreer, kan die volgende as voorbeeld geneem word. Soos plant en dier in die opskrif van hierdie artikel gebruik word, is hulle oorkoepelende "unique beginners" in die wetenskaplike taksonomie wat van die hoogste tot die laagste organismes insluit wat in die biologie geklassifiseer word. In die volkstaksonomie neem hulle ' $n$ laer rang in: hulle is "kleiner dinge wat uit die grond groei" en "kleiner dinge wat op land lewe". Maar die vraag is nou: moet plant met boom en bos, en dier met voël en vis gelykgestel word, of val boom en bos, en voël en vis in dieselfde kategorie as blom en hond onderskeidelik? Is plant en dier lewensvorme of generiese taxa? Omdat daar skynbaar oorkoepelende woorde vir "dinge wat uit die grond groei" en "dinge wat op land lewe" ontbreek, vorm die "unique beginners" versteekte kategorieë in Afrikaans. 
Van die drie kategorievlakke wat Rosch e.a. (1976) onderskei, besit hulle basiese kategorieë dieselfde belangrikheid as Berlin e.a. se generiese taxa. Hulle vlakke is:

superordinaat soos boom of voël wat baie heterogeen is en waarvan die lede min eienskappe deel;

basies soos eik en mossie waarvan die lede "(a) possess significant numbers of attributes in common, (b) have motor programs which are similar to each other, (c) have similar shapes, and (d) can be identified from averaged shapes of members of the class"; en

subbasies soos witeik en bergmossie waarvan die lede baie eienskappe met verwante kategorieë deel.

Hieruit blyk dat die toetse wat Rosch e.a. gebruik het, te doen het met die eienskappe wat tot modifikasie behoort: beweging en (of) vorm. Mervis en Rosch (1981) maak die volgende bevindings in verband met kategorieë: "(a) categories are internally structured by gradients of representativeness, (b) category boundaries are not necessarily definite, and (c) there is a close relation between attribute clusters and the structure and formation of categories". Hierdie "attribute clusters" beskryf Rosch e.a. (1976) ook as "information-rich bundles of co-occuring perceptual and functional attributes". Die gebruik van "perceptual" en "functional" is belangrik omdat dit dui op die mensgesentreerde toekenning van die eienskappe. "Concrete lexicon is neither a product of the human imagination nor a set of replicas copied from the world outside," beklemtoon Wierzbicka (1985: 346). "It is a product of human interpretation of the world. As such, it is a mirror in which the picture of reality blends with that of its interpreter."

\section{Karakterisering van die volkstaksonomiese stelsel}

\subsubsection{Karakterisering deur middel van kategorisasie en modifikasie}

Wierzbicka (1985: 173) meen dat die "attribute clusters" 'n deurslaggewende rol speel by volkskonseptualisering: nie net op generiese vlak nie, maar ook op sub- en suprageneriese vlak. Sy wil dus deur konseptualisering definisies opstel om die ander kategorieë van volksgenera te onderskei. "The whole folkgeneric concept usually has an internal logic to it," beweer sy (Wierzbicka 1985: 178), "so that most, if not all, of its components hang together, and explain and complement each other." Sy beklemtoon egter dat al die komponente in die voorgestelde definisies nie dieselfde status het nie: dié wat sy tussen hakies plaas, mag moontlik 'n opsionele deel van die konsep wees. Alhoewel die relatiewe status van die verskillende komponente nie arbitrêr is nie, is dit tog moeilik aantoonbaar: daarom kan die definisies nie in 'n essensiële en 'n nieessensiële deel geskei word deur eenvoudig die fisiese eienskappe (soos voor- 
koms) van die kulturele, "subjektiewe" eienskappe (soos funksie, stereotipiese gedrag en menslike houding) af te grens nie. Piotrowski (1986) kritiseer haar definisies juis op grond daarvan dat sy nie ' $n$ voldoende aanduiding gee van hoe hulle verkort kan word nie. "The important thing is not that the components of a definition should be few, or that they should be short, but that they should be well-justified," sê Wierzbicka (1985: 200) om die lengte van haar definisies te verdedig. Die lang definisies is ook die gevolg van haar poging om sirkulariteit te voorkom deur dié woorde wat gedefinieer word, in steeds eenvoudiger woorde te omskryf (sien Quine 1973 oor wat dit teoreties beteken, en vgl. Neubauer 1983 en Michiels en Noël 1983 oor wat dit prakties behels).

Hoe onderskei Wierzbicka (1985: 189-192) met behulp van haar definisies tussen lewensvorme en volksgenera? 'n Belangrike verskil lê in die basiese kategorisasie: die basiese kategorisasie vervat in die konsep "lewensvorm" is " $\mathrm{n}$ soort $\mathrm{X}$ waarvan daar baie verskillende soorte is ('n mens kan nie sê hoeveel nie)", en in die konsep "volksgenus" "n soort lewensvorm". 'n Lewensvorm word gekonseptualiseer as 'n superkategorie, 'n kategorie wat baie verskillende kategorieë insluit, en 'n volksgenus as 'n kategorie. Dit lyk asof plant, boom, bos, blom, dier, voël en vis almal superkategorieë, dus lewensvorme, en hond, kat, eik en els kategorieë, dus volksgenera, is.

Wierzbicka (1985: 228) wys daarop dat Berlin e.a. se onderskeiding van lewensvorme en volksgenera ' $n$ belangrike insig bring deurdat die volksgenera inderdaad semanties van die superkategorie lewensvorme en van die subkategorieë spesifieke taxa en variëteite verskil. Die konseptualisering van lewensvorme berus nie op individuele en selfs maatskaplike ervaring nie, maar is kultuuronafhanklik. In 'n sekere sin geld dit ook vir volksgenera: alhoewel daar ' $n$ bewustheid is van die bestaan van soorte volksgenera, is dit nie essensieel vir die konseptualisering van volksgenera nie (sien Wierzbicka 1985: 233-234). Die vlakke van sowel lewensvorme as volksgenera is meer geskik vir gebruik in verwysing na dinge as die subgeneriese vlakke, terwyl die subgeneriese vlakke veral dien om referente van mekaar te onderskei (sien Wierzbicka 1985: 236-239).

Wierzbicka (1985: 229-236) maak egter 'n onderskeid tussen groepe volksgenera soos eik en els aan die een kant en hond en kat aan die ander kant omdat hul subkategorieë verskil. By laasgenoemde kry 'n mens wat sy noem "monomiale subgenera" wat 'n tussenstadium vorm tussen volksgenera en spesifieke taxa wat sy weer omskryf as "binomiale subgenera". Die basiese kategorisasie van die konsep "binomiale subgenus" is " $n$ soort $X$ (een van die verskillende soorte $X$, nie so baie verskillende soorte nie) wat op sommige maniere, nie baie nie, verskil van wat ' $n$ mens jou wil of kan verbeel ontbreek om jou ' $n X$ voor te stel", en dié van die konsep "monomiale subgenus" is " $n$ soort $X$ (een van die verskillende soorte $X$, ' $n$ mens kan sê watter soorte) wat op sommige maniere, 'n mens kan sê watter maniere, verskil van wat 'n mens jou kan verbeel ontbreek om jou ' $\mathrm{X}$ voor te stel". "Monomiale subgenera" is dié besondere soorte subgenera soos hond wat wel in soorte ingedeel kan word soos poedel en terriêr. 
Hulle verskil van Berlin e.a. se spesifieke taxa deurdat hulle effens meer eienskappe besit en daarom effens meer ooreenstem met volksgenera. Albei hierdie soorte kan, soos binomiale genera, 'n onderskeidende eerste lid bykry (bv. Franse poedel, Maltese poedel en bulterriër, Skotse terriër). Die eerste lid van binomiale subgenera kan egter of kontrasterend óf neutraal funksioneer (bv. witeik en swarteik teenoor rooiels en klipels).

Wierzbicka onderskei hierdie volkstaksonomiese kategorië̈ verder met behulp van komponente wat, soos ek in par. 3.1.1 hierbo beweer het, modifikasies is. Die semantiese struktuur van konsepte soos kat en hond is skynbaar volgens dieselfde skema georganiseer: habitat, grootte, voorkoms, gedrag, verhouding met mense. Maar die superkategorieë soos dier, vis, voël, e.d. skyn meer individueel in hul essensiële semantiese struktuur te wees. Alhoewel die basiese kategorisasie by almal dieselfde is volgens dieselfde komponente (vgl. Witkowski en Brown 1978 wat die volgende beginsels van kategorisasie by lewensvorme noem: "conjuctivity (including binary opposition)", "criteria clustering", "marking" en "dimension salience"), is die volgorde van die dele skynbaar nie dieselfde nie. By dier is grootte saam met habitat die belangrikste, by vis en voël beweging saam met habitat, terwyl by plant, boom, bos en blom dit waarskynlik weer voorkoms of groeiwyse is. By subkategorieë, soos spesifieke taxa (binomiale subgenera), monomiale subgenera en variëteite, vorm die modifikasies dikwels deel van die samegestelde of gekwalifiseerde benamings.

\subsubsection{Kontrastering met verwante relasionele modelle}

Aan die einde van par. 2.1.1 hierbo het ek aangedui dat die redes vir wetenskaplikes se wens om bepaalde gewone name en volksname aan bepaalde plantsoorte te koppel, daarmee te doen het dat hierdie plante vir 'n sekere doel gebruik word.

Conklin (1962: 129) wys op meervoudige kategorieë en buitehiërargiese verwantskappe: kategorieë wat op vorm en voorkoms gebaseer is, kan oorvleuel met kategorieë wat op grond van funksie gemaak word, en verwantskappe met deel-geheel as basis is meer gekompliseerd as verwantskappe wat berus op klasinsluiting. Wierzbicka (1985: 293-295) toon aan hoe Rosch e.a. (1976) se resultate herinterpreteer moet word: sowel kollektiewe superkategorieë as suiwer funksionele konsepte blyk psigologies minder opvallend te wees as nie-kollektiewe konsepte van klasinsluiting waarop kollektiewe en suiwer funksionele kategorieë gebaseer is. Op grond van 'n stel vrae vir die verkryging van volkskennis het Frake (1964) 'n skema opgestel wat uit vyf tweerigtingverwantskappe bestaan, almal afgelei van hierdie vrae wat in pare gerangskik en potensiële omgekeerdes is: spesie-geslag, spesie-gebruik, bestanddeelgebruik, deel-bron, gebruik-bron. Gebruik vorm die basis van spesie, bron en bestanddeel. Dit gaan om soorte, bestanddele of dele afkomstig van dieselfde bron wat vir dieselfde doel gebruik word. Hulle besit ' $n$ bepaalde funksie soos 
nuttige kruie, of 'n sekere nie-funksie soos skadelike onkruid. Terselfdertyd vorm hulle heterogene versamelings.

\subsubsection{Verantwoording van die karakterisering}

Alhoewel sy uitgaan van Rosch e.a. se "attribute clusters" op grond waarvan hulle as psigoloë verskillende eksperimentele benoemings-, sorterings- en kategoriseringstake laat uitvoer het, staan Wierzbicka (1985: 196-197) tog skepties oor die resultate: "Semantic competence shows in the use of words, not in the ability to analyse them or explicate them."

Sy stel as vereiste dat die inhoud van haar definisies goed verantwoord moet wees deur linguistiese bewyse (Wierzbicka 1985: 200). Dit is juis dié linguistiese eienskappe wat ek hierbo in par. 2.2.1 gebruik het om wetenskaplike taal van die gewone taal te onderskei: semantiese assosiasies, metaforiese ontwikkelinge, e.s.m. Al dié aspekte kan as leidrade dien vir semantiese analise by die opstel van definisies. Sy onderskei direkte en indirekte linguistiese bewyse.

As direkte linguistiese bewyse noem sy die feit dat baie benamings van volksgenera groot leksikale families het wat met hulle saamhang en relevante attribute van 'n bepaalde volksgenus beklemtoon (bv. saal, runnik, ens. in verband met 'n perd) en dat sekere woorde met verskeie volksgenera saam gebruik kan word (bv. trop saam met beeste, skape, ens.). Onder indirekte linguistiese bewyse klassifiseer sy die linguistiese kenbaarwording van modifikasies soos grootte, vorm, kleur, e.s.m. wat gebruik word (sien par. 3.2.1 hierbo) om volksgenera van super- en subkategorieë te onderskei.

Wierzbicka (1985: 211) beskou volksdefinisies slegs as data waarmee die analis sy konseptualisering van 'n benaming kan begin. Die moontlikheid van die gebruik van volksdefinisies is deur Weinreich (1962) genoem, deur Wiegand (1983 en 1984) verder ontwikkel en effens later ook deur Stock (1986) gepropageer. Wiegand (1984: 22) gaan uit van "the theory of meaning-in-use" wat "the meaning of an expression as correct or rule-governed use" interpreteer. Om te bepaal watter predikate in ' $n$ "lexical paraphrase" behoort, moet die eienskappe daarvan genoem kan word. Substantiewe moet volgens Wiegand (1984: 25) die volgende eienskappe as "lemma-signs" besit: "They must have as high a degree of usability as possible in order to identify that class of objects in 'usual' denomination contexts referred to in whole or in part by the lemma-sign in 'usual' texts." Op grond hiervan het hy 'n toets aangewend om die skaal van bruikbaarheid van beskrywende uitdrukkings te bepaal wat geskik is om 'n klas voorwerpe te identifiseer. Met behulp van die resultate hierdeur verkry, kon hy 'n definisie van suurlemoen opstel wat nie die wetenskaplike nie, maar die gewone gebruik weerspieël (sien Wiegand 1984: 25-28). Reeds Malone (1940) het al met behulp van sitate bewys hoe dié twee gebruiksaspekte van 'n woord soos mahogany kan verskil. 
Behalwe dat verklarings van volksbiologiese konsepte deur linguistiese bewyse gestaaf moet word, moet hulle ook, soos Wiegand gedoen het, deur informante se reaksies getoets word. Indien reaksies verskil, kan dit, benewens aan dialektiese verskille, veral aan verskille in individuele lewenservaring toegeskryf word.

Te oordeel na die semantiese bewyse wat steun op die antropo- en psigolinguistiese bewyse soos hierbo aangevoer, word konkrete konsepte hoofsaaklik op ' $n$ perseptuele en funksionele basis gevorm. Wierzbicka (1975: 214-218) is van mening dat hierdie konsepte nie ' $n$ onbeperkte variasie het nie: daar is ' $n$ konsepmaksimum en ' $n$ konsepminimum binne ' $n$ bepaalde kultuur. Hier gaan dit nie om individuele kennis of assosiasies wat verband hou met ' $n$ bepaalde onderwerp (soos in die biologiese wetenskappe) nie, maar om die maksimum en minimum konsepte wat gewone mense in 'n spraakgemeenskap sien as 'n gedeelde stereotipe op grond van hul lewenservaring in daardie gemeenskap. Daar is ' $n$ duidelike grens tussen betekenisse wat ' $n$ mens nie voldoende ken om hulle te kan gebruik nie en betekenisse wat 'n mens onvolledig ken, maar voldoende om hulle te kan gebruik. Indien iemand hom nie 'n voorwerp kan voorstel nie, dan het hy nie 'n onvolledige nie, maar 'n onvoldoende en dus onbruikbare konsep daarvan. Al die kriteria wat die spraakgemeenskap as geheel gebruik, is in die stereotipe ingesluit. Dit is moontlik dat die stereotipe van 'n sekere voorwerp vanweë kulturele redes in 'n sekere spraakgemeenskap omvattender is as in ' $n$ ander. Nie al die lede van 'n spraakgemeenskap ken egter al die stereotipes of ken hulle volledig nie. Watter stereotipes hulle ken, en of hulle hulle volledig ken, hang van hul individuele lewenservaring af. Die verskil in individuele vermoëns kan vasgestel word deur die kriterium van aktiewe gebruik.

Hieruit blyk dat die definisies van plante en diere in die volksbiologie dié in die wetenskaplike biologie slegs gedeeltelik sal dupliseer. Die konseptualisering van volksbiologiese name is sekerlik meer onderworpe aan interpersoonlike variasie as die konseptualisering van ander benaminge in die gewone taal, nie net vanweë gebrekkige lewenservaring van individue nie, maar ook vanweë die onsekere inhoude van die denotata.

Hieruit blyk ook verder dat die woordeskat van plant- en diername in die volksbiologie net gedeeltelik met dié in die wetenskaplike biologie ooreenstem. Daar is baie gewone benaminge wat in die wetenskaplike biologie gebruik word, wat nie in die kollektiewe bewussyn van die spraakgemeenskap bestaan nie. Dit beteken dat hulle nie tot die woordeskat van die gewone taal deurgedring het nie.

Uit die voorafgaande volg dat die mikro- en die makrostruktuur van 'n woordeboek van die gewone taal deur linguistiese bewyse bepaal kan word: die aard van die definisies is onderworpe aan die konsepmaksimum en -minimum en die omvang van die woordeboek aan die woordeskat wat maksimaal en minimaal deur die spraakgemeenskap gekonseptualiseer kan word. 


\section{Slot}

Die komplementariteit van Baldinger se twee velde, onomasiologie en semasiologie, wat ek in par. 2.2.2 hierbo gebruik het om die wetenskaplike en die volkswetenskaplike benaderings te presiseer, kan nou verder ondersoek word: hulle is sowel struktureel as funksioneel. Op strukturele vlak kan die uitgangspunte soos volg teenoor mekaar gestel word: terminologie volg 'n onomasiologiese benadering, vanaf die konsepte na die terme wat hulle benoem; die leksikografie volg 'n semasiologiese benadering, vanaf die woorde wat bepaalde begrippe aandui, na hul betekenisse. Op funksionele vlak kan die doelstellings soos volg gekontrasteer word: terminologie se primêre doel is om skrywers te help om tekste voort te bring; die leksikografie se basiese doel is om lesers in staat te stel om tekste te interpreteer.

Soos ek in par. 2.2.3 hierbo aangedui het, is die ensiklopediese en die standaardwoordeboeke twee kontrasterende vorme van die leksikografie. Tussenin lê daar ook die omvattende algemene woordeboek. In 'n wetenskaplike kultuur word die volkswetenskaplike konsep dikwels gekleur deur die wetenskaplike konsep van 'n benaming, veral wanneer die gewone naam en die volksnaam ooreenstem. Dit sal in 'n omvattende algemene woordeboek weerspieël moet word (vgl. Piotrowski 1986: 58-60) omdat hierdie vermenging van wetenskaplike en volkswetenskaplike konseptualisering dikwels in populêrwetenskaplike tekste voorkom (vgl. par. 2.1.1 hierbo).

\section{Verwysings}

Baldinger, Kurt. 1980. Semantic Theory: Towards a Modem Semantics. Vertaal uit die tweede Spaanse uitgawe, Madrid, Ediciones Alcalá, 1977, deur William C. Brown en geredigeer deur Roger Wright. Oxford: Basil Blackwell.

Bamard, K.H. 1947. A Pictorial Guide to South African Fishes: Marine and Freshwater. Kaapstad: Maskew Miller Bpk.

Béjoint, Henri. 1988. Scientific and Technical Words in General Dictionaries. International Journal of Lexicography 1: 354-368.

Berlin, Brent, Dennis E. Breedlove en Peter H. Raven. 1973. General Principles of Classification and Nomenclature in Folk Biology. American Anthropologist 75: 214-242.

Bühler, Karl. 1934. Sprachteorie: Die Darstellungsfunktion der Sprache. Jena: Gustav Fischer.

Callebaut, B. 1983. Les vocabulaires techniques et scientifiques et les dictionnaires: le cas d'une nomenclature des sciences naturelles. Cahiers de lexicologie 43 (2): 33-52.

Chaffin, Roger en Douglas J. Hermann. 1988. The Nature of Semantic Relations: A Comparison of Two Approaches. Evens, Martha Walton (Red.). 1988: 289-334.

Chippindall, L.K.A. 1946. Gewone name dan grassoorte in Suid-Afrika. Pretoria: Departement van Landbou.

Conklin, Harold C. 1962. Lexicographical Treatment of Folk Taxonomies: Householder, Fred. W. en Sol Saporta (Reds.). 1967: 119-141. 
Cruse, D.A. 1986. Lexical Semantics. Cambridge: Cambridge University Press.

De Winter, B., Mayda de Winter en D.J.B. Killick 1966. Ses en sestig Transvaalse bome. Pretoria:

Departement van Landbou-tegniese Dienste.

De Winter, B. en J. Vahrmeijr. 1972. Die Nasionale Boomlys. Pretoria: J.L. van Schaik Bpk.

Du Toit, Elma L. 1989. Sosiolinguistiese gegewens in handwoordeboeke van Afrikaans. Ongepubliseerde M.A.-skripsie. Universiteit van Stellenbosch.

Evens, Martha Walton (Red.). 1988. Relational Models of the Lexicon: Representing Knowledge in Semantic Networks. Cambridge: Cambridge University Press.

Evens, Martha, Judy Markowitz, Bonnie Litowitz, Raoul Smith en Oswald Wemer. 1980. Lexical-semantic Relations: A Comparative Suroey. Edmonton: Linguistic Research lnc.

Frake, Charles O. 1964. Notes on Queries in Anthropology. Romney, A. Kimball en Roy Goodwin D'Andrade (Reds.). 1964: 132-145.

Frawley, William. 1980-1981. Lexicography and the Philosophy of Science. Dictionaries 2-3: 18-27.

Frawley, William. 1988. Relational Models and Metascience. Evens, Martha Walton (Red.). 1988: 335-372.

Geeraerts, D. 1984. Types of Semantic Information in Dictionaries. Ilson, Robert (Red.). 1987: 1-10.

Geeraerts, D. 1985. Les données stéréotypiques, prototypiques et encyclopédiques dans le dictionnaire. Cahiers de lexicologie 46 (1): 27-43.

Gill, E. Leonard. 1936. A First Guide to South African Birds. Kaapstad: Maskew Miller Bpk.

Gill, E. Leonard. 1945. A First Guide to South African Birds. Derde uitgawe. Kaapstad: Maskew Miller Bpk.

Gill, E. Leonard. 1964. A First Guide to South African Birds. Sewende uitgawe. Hersien deur J.M. Winterbottom. Kaapstad: Maskew Miller Bpk.

Hartmann, R.R.K. (Red.). 1984. LEXeter '83 Proceedings: Papers from the International Conference on Lexicography at Exeter, 9-12 September 1983. Tübingen: Max Niemeyer Verlag.

Hauptfleisch, D.C. 1982. Die Woordeboek van die Afrikaanse Taal: Verlede, hede en toekoms. Van Rensburg M.C.J. (Red.). 1982: 89-112.

Housẹholder, Fred. W. en Sol Saporta (Reds.). 1967. Problems in Lexicography. Bloomington: Indiana University.

Hyldgaard-Jensen, Karl en Arne Zettersten (Reds.). 1985. Symposium on Lexicography II: Proceedings of the Second International Symposiumi on Lexicography May 16-17, 1984 at the University of Copenhagen. Tübingen: Max Niemeyer Verlag.

Ilson, Robert (Red.). 1987. A Spectrum of Lexicography: Papers from AlLA Brussels 1984. Amsterdam: John Benjamin's Publishing Co.

Iris, Madelyn Anne, Bonnie E. Litowitz en Martha Evens. 1988. Problems of the Part-Whole Relation. Evens, Martha Walton (Red.). 1988: 261-288.

Jeffrey, Charles. 1973. Biological Nomenclature. Londen: Edward Amold Ltd.

Malone, Kemp. 1940. On Defining mahogany. Language 16: 308-318.

Markowitz, Judith. 1988. An Exploration into Graded Set Membership. Evens, Martha Walton (Red.). 1988: 239-260.

McDavid, Raven I., Jr. en R. Duckert (Reds.). 1973. Lexicography in English. The New York Academy of Sciences. 
Mel'chuk, Igor en Alexander Zholkovsky. 1988. The Explanatory Combinatorial Dictionary. Evens, Martha Walton (Red.). 1988: 41-74.

Mervis, Carolyn B. en Eleanor Rosch. 1981. Categorization of Natural Objects. Annual Review of Psychology 32: 89-115.

Michiels, Archibal en Jacques Noël. 1983. The Pro's and Con's of a Controlled Defining Vocabulary in a Learner's Dictionary. Hartmann, R.R.K. (Red.). 1984: 385-394.

Neubauer, Fritz. 1983. The Language Exploration in Monolingual Dictionaries. Hartmann, R.R.K. (Red.). 1984: 117-123.

Palmer, Eve en Norah Pitman. 1972. Trees of Southem Africa, cooering all known Indigenous Species in the Republic of South Africa, South-West Africa, Botswana, Lesotho and Swaziland. (3 dele) Kaapstad: A.A. Balkema.

Piotrowski, Tadeusz. 1986. Defining Natural-kind Words. Snell-Homby, Mary (Red.). 1988: 55-62.

Prozesky, O.P.M. 1974. Voëls van Suider-Afrika: Veldgids. Johannesburg: Perskor-uitgewery.

Putnam, Hilary. 1975. The Meaning of "meaning". Putnam, Hilary. 1975: 215-271.

Putnam, Hilary. 1975. Mind, Language and Reality. Philosophical Papers, Volume 2. Cambridge: Cambridge University Press.

Quine, W.V. 1973. Vagaries of Definition. McDavid, Raven 1., Jr. en R. Duckert (Reds.). 1973: 247-252.

Roberts, Austin. 1940. The Birds of South Africa. The Trustees of the South African Bird Book Fund.

Roberts, Austin. 1957. Roberts' Birds of South Africa. Tweede uitgawe. Hersien deur G.R. McLachlan. The Trustees of the South African Bird Book Fund.

Roberts, Austin. 1970. Roberts' Birds of South Africa. Derde uitgawe. Hersien deur G.R. McLachlan en R. Liversidge. Kaapstad: The Trustees of the John Voëlcker Bird Book Fund.

Roberts, Austin. 1985. Roberts' Birds of Southern Africa. Vyfde uitgawe. Hersien deur Gordon Lindsay Maclean. Kaapstad: The Trustees of the John Voëlcker Bird Book Fund.

Romney, A. Kimball en Roy Goodwin D'Andrade (Reds.). 1964. Transcultural Studies in Cognition. Special Publication. American Anthropologist 66.

Rosch, Eleanor. 1975. Cognitive Representation of Semantic Caregories. Joumal of Experimental Psychology: General 104: 192-233.

Rosch, Eleanor, Carolyn B. Mervis, Wayne D. Gray, David M. Johnson en Penny Boyes-Bream. 1976. Basic Objects in Natural Categories. Cognitize Psychology 8: 382-439.

Savory, Theodore. 1962. Naming the Lioing World: An Introduction to the Principles of Biological Nomenclature. Londen: The English Universities Press Ltd.

Scholtz, J. du P. 1975. Naamgewing aan plante en diere in Afrikaans: Bydrae tot 'n geskiedenis dan die Afrikaanse woordeskat. Tweede uitgawe. Kaapstad: Nasou Bpk.

Smith, C.A. 1966. Common Names of South African Plants. Geredigeer deur E. Percy Phillips en Estelle van Hoepen. Pretoria: Departement van Landbou-tegniese Dienste.

Smith, J.L.B. 1949. The Sea Fishes of Southern Africa. Central News Agency Bpk.

Smith, Margaret M. 1975. Common and Scientific Names of the Fishes of Southern Africa. Part 1: Marine Fishes. Grahamstad: The J.L.B. Smith Institute of lchthyology.

Sanith, Margaret M. en Phillip C. Heemstra (Redsi). 1988. Smith's Sea Fishes. Johannesburg: Southern Book Publishers (Pty.) Ltd. 
Snell-Homby, Mary (Red.). 1988. ZulriLEX '86 Proceedings: Papers read at the EURALEX Intemational Congress, University of Zürich, 9-14 September 1986. Tübingen: Francke Verlag.

steam, William T. 1966. Botanical Latin: History, Grammar, Syntax, Terminology and Vocabulary. Londen: Thomas Nelson and Sons Ltd.

Stock, Penelope. 1986. The Structure and Function of Definitions. Snell-Hornby, Mary (Red.). 1988: 81-89.

Swanepoel, P.H. 1989. Botsing tussen leksikografiese beginsel en leksikografiese praktyk: Enkele gedagtes oor die terminologiebeleid van die WAT. Suid-Afrikaanse Tydskrif vir Taalkunde 7: 6-19.

Van Rensburg M.C.J. (Red.). 1982. Kongresreferate. 18de Jaarlikse Kongres. Linguisteoereniging oan Suid-Afrika. Rhodes Universiteit, Grahamstad. Bloemfontein: Universiteitsdrukkers UOVS.

Van Wyk, P. 1973. Bome zan die Nasionale Krugerwildtuin. (2 dele) Johannesburg: Perskor-uitgewery.

Watt, J.M. en M.G. Breyer-Brandwijk, 1962. The Medicinal and Poisonous Plants of Southern and Eastern Africa, being an Account of their Medicinal and Other Uses, Chemical Composition, Phamacological Effects and Toxicology in Man and Animal. Tweede uitgawe. Edinburg. E. and S. Livingstone Ltd.

Weinreich, Uriel. 1962. Lexicographic Definition in Descriptive Semantics. Weinreich, Uriel. 1980: 295-314.

Weinreich, Uriel. 1980. On Semantics. Geredigeer deur William Labov en Beatrice S. Weinreich. Philadelphia: University of Pennsylvania Press.

Wells, M.]., A.A. Balsinhas, H. Joffe, V.M. Engelbrecht, G. Harding en C.H. Stirton. 1986. A Catalogue of Problem Plants in Southem Africa incorporating the National Weed List of South Africa. Pretoria: Departement van Landbou en Watervoorsiening.

Wiegand, Herbert Enst. 1983. On the Structure and Contents of a General Theory of Lexicography. Hartmann, R.R.K. (Red.). 1984: 13-30.

Wiegand, Herbert Ernst. 1984. Eine neue Auffassung der sog. lexikographischen Definition. Hyldgaard-Jensen, Karl en Ame Zettersten (Reds.), 1985: 15-100.

Wierzbicka, Anna. 1985. Lexicography and Conceptual Analysis. Ann Arbor: Karoma Publishers Inc.

Witkowski, Stanley R. en Cecil H. Brown. 1978. Lexical Universals. Annual Review of Anthropology 7: $427-451$. 